\title{
Exile, Return and Restitution in the Czech Republic
}

\section{Katherine Vadura, University of South Australia}

The period of development of a new state brings with it many experiences spanning the political, social and economic. The individuals and communities that make up the new state together forge a path that does not always run smoothly. The movement of people within the new borders and across borders is often a result of reactions to events both internal and external, and the resulting experiences can impact on people's lives in very fundamental ways. The experience of exile, its causes and consequences, can shape the development of a state and change the course of history. The Czech Republic or Czechoslovakia as a newly created state in 1918 had in the relatively short span of about seventy years brought to the people residing within its territory a number of different experiences of exile. The focus of this paper is on the Sudeten Germans, a former minority in the Czech lands sent into exile at the end of World War 2, my specific interest being to analyse key periods in exile experiences between 1918 and 1995. The development of the relationship between the Czechs and the Sudeten Germans still remains problematic in the eyes of many of the protagonists. Among the many questions raised by that relationship is whether this form of exile was a legislated banishment or a form of mere displacement. In addition, the question of guilt has arisen over the years, both as a mechanism for invoking the forced transfer of a population and also as a justification for receiving recompense. The conceptual basis for this paper centres on nationalism, identity politics and minority rights as an underlying framework for analysing the experience of exile of the Sudeten Germans and their complex relationship with the Czechs, in the attempts to establish a homeland.

The end of the First World War brought with it many changes to the geo-political landscape of Europe. It resulted in the defeat and dismantling of empires, and gave independence and new international standing in the form of statehood to territories which 
had previously been under their jurisdiction. The peace settlements after the war resulted in the creation of a number of new nation-states including Czechoslovakia. As the granting of statehood had been based on the right to self-determination according to the principle of nationality, a common problem for all of the newly independent states was the place of minorities. This extended to how to include or integrate these sometimes-reluctant minority groups into the new state framework. The German minority in the Czechoslovak state found itself to be part of a state that it had not wanted to join, and in a subservient position, a reversal of its previous majority status.

The exile experiences in the Czech lands occurred after significant political upheavals that destabilised the institutions and structures of the state. These population movements occurred after the two world wars and also as a result of border revisions and regime changes, and they impacted on all nationalities in the new state. Similarly the experiences of return and restitution that flowed from the various exiles have also been varied in the post-war and post communist periods.

\section{What is the relevance of the metaphor of guilt for exile?}

The struggle between two of the nationalities that had co-existed in the territory of the former Czechoslovakia and resulted in various experiences of exile, produced a cyclical effect which in this paper is represented by the metaphor of guilt. Guilt represents a metaphor for the consequences and implications surrounding the pursuance of particular actions. As Barkan states, 'guilt is a potentially powerful mechanism for transforming daily sentimentality and universal humanitarianism into a political agenda' $(2000,316)$. In the example discussed in this paper, the political agenda manifests itself in a discourse on restitution.

One community's guilt may have been another community's freedom, but freedom brings with it new guilt. This new guilt stems from an entrapment in the past. Following the end of World War II, Karl Jaspers (1967) discussed and debated the question of German guilt surrounding the war, and the concept of collective guilt. Guilt can arise by virtue of being part of a particular national group. This means that there is a degree of responsibility for the wrongs committed by that group simply for being a member of that group. Therefore freedom can only be achieved by taking or acknowledging responsibility and then acting 
accordingly, by restitution or the making up for wrongs. All national groups participate in this cycle, which is self perpetuating until all parties acknowledge their responsibility (both collective and individual). The act of acknowledgment is the first step in the process of freedom towards achieving purification or reconciliation. True freedom and breaking of the cycle at the national level can only be achieved if authority is handed over to a higher body, a strong supporting argument for the development of the supranational institutions of today. According to Jaspers, purification through restitution is the only way to achieve freedom from any form of guilt.

\section{Background to exile - the Sudeten German dilemma}

War and conflict proved to be a consistent backdrop to developments between the Sudeten Germans and the Czechs. Change, in the sense of historical change, was inevitably a catalyst for dramatic solutions in the attempt to create an atmosphere of stability. The issues and questions surrounding the Sudeten Germans have remained true to this drive, and their appearance on the international stage as a minority has stood as testimony to their continued dissatisfaction. The peace conferences at the end of the First World War created a number of new nation-states out of what had been the Austro-Hungarian Empire, of which the Czechoslovak Republic was just one. At the same time, those Germans who had lived scattered across the entire territory of the Austro-Hungarian Empire remained as minorities in these new states. Thus, the Sudeten Germans were relegated to minority status with the formal recognition of the Czechoslovak Republic in October 1918. Depending on the structure of the new states, these German minorities were given either a greater or lesser political voice. In the case of the Sudeten Germans, whilst they were given political and human rights, they never attained the status of equal partners with the Czech population. The Czechoslovak Republic became one of the new states that consisted of a patch work of nationalities, of which the Sudeten Germans formed the single largest minority, comprising a population that was larger by one million than the Slovak population in the Republic. The conception of the state in this form presented an increased probability of it falling into a situation of instability primarily as a result of the size of the Sudeten German group and their dissatisfaction with not achieving equal status or the right to self determination. In relation to the notion of identity politics, this representation of a multi-ethnic state raised significant questions concerning the feelings of belonging of all the groups that found themselves to have a minority status. As 
Campbell says, both the Czechs and the Sudeten Germans had a similar view of nation and homeland. However, when the right to self determination was not granted to all national groups, in becoming a minority the Sudeten Germans found themselves in a situation of competing loyalties, where the nation and the homeland were not congruent (Campbell 1975, 75-76). The foundation for the first phase of the cycle of guilt and freedom had been laid.

In summary, the Czech and Slovak peoples were successful in their united bid for self determination and the creation of their own nation-state. The Sudeten Germans had miscalculated on the interests of their German neighbours, and the subsequent reaction of the Allies. The Sudeten Germans had attempted to explore a number of avenues by which to also achieve self determination, including committing themselves to becoming a part of Greater Austria, and on another occasion to joining the German Reich, which had been met with disinterest on the part of Germany. Therefore, to all intents and purposes the question of international recognition of the right to self determination for the Sudeten Germans was resolved, in that it was denied, and the beginnings of a sense of exile inside a new state developed. The only remaining option was for this minority to work within the confines of the new state and attempt to seek some form of right to autonomy through the available democratic channels.

\section{Munich Agreement and a new experience of exile}

September 1938 was to prove to be the deciding month both for the future of the First Republic of the Czechoslovak state and for the fate of the Sudeten Germans. Time was clearly running out for the Czech head of state Eduard Beneš, and all attempts at negotiation to settle the tensions and growing conflict with the Sudeten Germans had failed. The fate of the Czechoslovak state seemed to rest with the benevolence of Hitler and the combined strength of Britain and France. When Hitler demanded the return of the Sudeten territories to the Reich at this time with the open threat of war, the appeasement policy of Britain prevailed and the British and French governments agreed on a proposal that allowed for the transfer to Germany of certain Sudeten territories where the German population made up more than fifty percent of the total population. The Czechoslovak government, and in particular Beneš, found this most objectionable, especially since they had always upheld the idea that they would not tolerate the international community 
meddling in their domestic affairs. Thus, they found the proposal to be unviable and rejected it, a move that angered both Britain and France to the point where they threatened to renege on the terms of their alliance. Only the Soviet Union promised to stand by the Czechoslovak Republic and send assistance should the country come under any direct threat. This promise was not binding in that the Soviet Union, under the terms of its treaty with the Czechoslovak Republic, was only obliged to assist if France interceded first.

When it became clear that Czech isolation was complete and peace had been maintained, Hitler opted to again push with further demands, this time in relation to disputed border claims by Hungary and Poland. Hitler set the deadline of October 1, 1938, for the return of the Sudeten lands, after which he proclaimed decisions about new borders could be made. The use of the idea of return in itself tapped into the issues of identity and belonging that had been left unresolved from the Sudeten point of view. In a final attempt to avoid war, both Britain and France sent separate requests to Hitler to negotiate. Finally, on September 28 Hitler agreed to a conference with Britain, France and Italy. When the leaders of the four countries arrived in Munich the next day, the result of the conference was already a forgone conclusion; Hitler's demands would be met at the expense of the Czechoslovak Republic, which importantly was missing from any of the negotiating process. The Sudeten Germans were considered to be represented de facto by Hitler, as he had been the architect of the Munich crisis. On September 30, the Munich Agreement was finalised and accepted. The terms of the agreement saw all of Hitler's demands realised; the occupation of the Sudeten territories would be completed in five stages, a transfer of the Czech population would take place over the following six months, and all Sudeten German prisoners being held for political offences were to be released (Kral 1964, 336). This heralded a new phase of exile experiences in the Czech lands.

The Munich Agreement was received with jubilation on the part of most Sudeten Germans and with great sadness on the part of the Czechs. The repercussions of the Munich Agreement were to be felt for many years by the Czechs, both in the anger and hostility harboured against the Sudeten Germans and in their sense of abandonment by their allies. The latter feeling was particularly skilfully used by Czech nationalists and advocates of pan Slavism during and after the war. The lack of Czechoslovak representation at the Munich conference resulted in the Munich Agreement being referred to as a diktat by the Czechs - the future of their state was being decided by external issues, in the sense of 
European and international security and political goals, and they were denied any opportunity to defend their state. The Munich Agreement resulted in a frenzy of claims against the Czechoslovak state from all sides: Germany regained its oppressed German minority; Poland revived its claim to the disputed Tešin region; Hungary eagerly sought to regain the border villages that had become part of Slovakia in the post-war carve up after the Treaty of Versailles. Czech bureaucrats struggled in an up hill battle in giving adequate attention to all the claims, while at the same time trying not to aggravate the situation in case more territory were lost. The resentment created by the Munich Agreement was so strong that it permeated all future foreign policy negotiations, directly in relation to Germany, and indirectly in relation to other European powers. Munich thus marked the end of the First Republic, and the ensuing Second Republic was short lived and followed by occupation and war.

For many Czechs the Sudeten Germans represented a so-called fifth column, a disloyal minority vis-à-vis the state, nation and homeland, and a group that deserved to be expelled. This idea was in many ways a continuation of thought that had already existed at the time of the creation of the Czechoslovak Republic. As the state had been established on the principle of nationality, an inherent tension between loyalty to the state and to the nation and homeland existed for those not of the Czech majority. After Munich, Beneš felt 'that when Czechoslovakia ... managed to recover her historic borders there would have to be a 'radical and final' solution of the German minority problem' (Cornwall 1992, 185).

\section{The impact of Munich and the politics of exile}

It must be remembered that not all of the Sudeten Germans supported the Munich Agreement, or participated in post Munich jubilation or the subsequent occupation of the Czech lands. Many of the Sudeten German Social Democrats found themselves in a situation where they were persecuted and sent to concentration or labour camps for their anti-Hitler stance. In the Czech lands, the Sudeten German Social Democrats had a difficult time, and were consistently let down by the Czech government. Many of them, in fact, were turned over to the Nazis by the Czechs as anti-fascists. The Czechs sent 20,000

Sudeten Social Democrats, who had fled to the Czech lands in search of safety, back to the Sudeten German territories. Only 3000 of the Social Democrats made it to exile in England (Prinz 1995, 73). 
By October 7, 1938, the Nazis occupied the four border areas outlined in the Munich Agreement. A policy of transfers was drawn up to ensure that those Czechs were removed from there, setting a precedent for the use of expulsion as a means to establish ethnic homogeneity in a particular territory. Beneš remained president for only a short time after the conclusion of the Munich Agreement. He left the Czech lands on October 22, ending up in Britain where he was persuaded to take up the position of leader in exile (Paneth 1943, 90). By 1940, a government was formed out of the National Committee, and Beneš was elected as its President. Other former members of the Czechoslovak Parliament who had fled the country rose to prominence in the new government in exile.

Politically active members of the Sudeten Germans communists also fled to London, where Wenzel Jaksch, a social democrat, came to be known as one of the more outspoken members of the Sudeten German community. ${ }^{1}$ Therefore, a semblance of democracy was created by the formation of an opposition, which on the Czech side included the former prime minister and leader of the Agrarians, Milan Hodza, as well as the Sudeten Germans in exile. However, due to fundamental differences in belief, the Sudeten Germans in exile found themselves unable to present a unified stance, a factor that would further destabilise their position in the future Czechoslovakia. The war years for Beneš and the rest of his government in exile were spent focussed on the restoration of the Czech state by lobbying for the annulment of the Munich Agreement and finding a lasting solution to the minorities problem. Beneš was ultimately successful in lobbying for recognition of his government as the free Czechoslovak government. Importantly for the fate of the Sudeten Germans, it was from his position in exile that he proceeded to draw up his plans for the post-war Czechoslovak Republic, one without minority issues. For the Sudeten Germans there was a further division between the followers of Jaksch who fought against the calls for expulsion, and those Sudeten Germans who became a part of Beneš's inner circle and supported his plans for post-war Czechoslovakia.

\footnotetext{
1 In discussions between Jaksch and Beneš in early 1939 it was clear that a resolution to the Sudeten German question needed to be found. Jaksch at this point in time still felt confident that a post-war multinational state would be established, along the lines of the earlier proposed Swiss model. (Vondrová 1994, 19, Doc. 4).
} 
During the period of the Protectorate in the Czech lands there was only one constitutional element that remained free; the presidency in exile. Beneš was the holder of this office, and the argument followed that as his resignation after Munich came about as a result of external pressure, his presidency was invalid. That said, Beneš nonetheless 'became the obvious leader and focal centre of Czechoslovak democracy as reconstituted abroad' (Taborsky 1945, 148). Beneš was determined not to make what he considered to be the same mistake again, namely to rely on the western powers for assistance. Munich had convinced him of the futility of pursuing such action. The idea of western patronage had failed, and this lead to his decision to choose a new patron with the feeling that a Slavic link might prove more reliable. Therefore, the Czech government in exile proceeded to conclude several important treaties with the Soviet Union. The Košice Program established a new policy in relation to questions of identity and belonging in the redefined state. As the war drew to a close, Beneš and his cabinet followed one of his ministers Němec back to the liberated regions of Czechoslovakia from Moscow (Roucek 1948, 369).

\section{Solving the minorities problem in the Czech lands}

Attempts at restoring the balance in the post-war state were focussed on implementing a lasting solution in relation to the perceived problem of a disloyal German minority. The pursuit of ethnic homogeneity by eliminating or removing the unmanageable minority, in this instance through transfer, had the end goal of creating more favourable conditions for the majority Czech population. From the Czech side there were a number of justified reasons for pursuing their policy of 'removing' the minorities problem. Shortly after the Munich episode, Beneš had decided that if there was to be any stability in the future state, a solution would have to be found to the minorities problem, as he held the Sudeten Germans almost solely responsible for the destruction of the Czechoslovak Republic. In 1939 Beneš presented an idea for this solution. This idea was based on a system of cantons (župa), which had already been debated in the 1920s. The importance of this idea lay in the fact that these cantons would be ethnically or nationally homogenous (Cornwall 1992, 186).

On the other hand, Czech nationalists were in favour of a far more radical solution to the Sudeten problem, preferring a radical cleansing of the Czech lands of all ethnic Germans after the war. Through their influence Beneš adopted the expulsion solution with regard to 
the Sudeten problem, a solution for which he spent the majority of the war years attempting to gain international acceptance. After 1941, Beneš was no longer making any reference to the introduction of a canton system. The years during the war were then spent trying to come up with an equitable expulsion solution. The idea of expelling or transferring an unwanted population was not a new one. An international precedent for the transfers was found in the 1920s post-war treaty allowing for an exchange of populations between Greece and Turkey. The rationale for the Potsdam transfers was established despite the fact that at the time it was felt that the principle of transfer as a means of solving a minority problem should not be repeated: the resulting trauma was not worth the net gain (Macartney 1996). The process of gaining international approval for the expulsion of the Sudeten Germans thus took several years. This also meant that it was no longer possible for the Sudeten Germans and Czechs to work together in exile, and the Sudeten German Social Democrats embarked on a mission of protest against the expulsion idea. However, the harshness of Nazi rule in the Czech lands led to a lack of sympathy for the Sudeten Germans in the international arena.

In May 1941, Beneš made his first public speech in Britain advocating a solution to the Sudeten problem by way of population transfer. The following year Beneš proceeded to pursue the expulsion solution, only this time he raised the guilt criterion. The idea was initially rejected by the Allies, but by the end of the war they too had accepted the idea (Cornwall 1992, 189-92). Therefore, in the early 1940s the dialogue was changing from what sort of a solution to implement to how many Sudeten Germans should be expelled in order to maintain internal stability in Czechoslovakia after the war had ended.

The idea of redrawing Czech borders with Germany, and thereby reducing the German population in the Czech lands, was again proposed, just as it had been in 1918 and 1919. However, by the end of 1943 Beneš was being advised by a Molotov deputy 'simply to chase the Germans out without ceding any territory' (Cornwall 1992, 188). Beneš maintained that ideologically the Sudeten German problem was a fight on a global scale between democracy and totalitarianism; therefore the expulsion was equated with moral restitution. In opposition to this, Jaksch questioned how the expulsion of solely the Sudeten Germans could be justified on the basis of collective guilt/collective responsibility if the Slovaks were also not expelled. This argument was based on the premise that the Slovak population was just as responsible for the post-Munich break up of the state. To 
this argument, Beneš responded by saying that 80 percent of the Slovaks had not abandoned their loyalty to Czechoslovakia (Prinz 1995, 79-81). Beneš openly expressed the justification for territorial transfers to be grounded in the principle of guilt, in particular, the collective guilt of the German minority in the destruction of the Czechoslovak state and that minority's collaboration with Hitler. He then had to decide to what degree the concept of guilt should be applied: to all Sudeten Germans or only to those who were confirmed Nazis. ${ }^{2}$

\section{The implications of the Beneš Decrees}

One of the more controversial decisions of the government in exile under Beneš was to enact a set of decrees. In Košice the now provisional government released its new program, the important points of which related to the expulsion and denationalisation of the Sudeten Germans and the confiscation of their property, unless they could prove their loyalty to the Czechoslovak state. This program was made into law, thus legitimising what has come to be known as the Beneš Decrees. Due to the recognition of the continuity of the office of the President in exile, the decrees passed by Beneš were converted into law after the war when the provisional National Assembly took on its executive role in the liberated Czechoslovak state. The Assembly then passed a constitutional law in March 1946, which converted all of President Beneš' decrees into law. The two most controversial decrees passed by Beneš, in relation to the Sudeten Germans, were those concerning the loss of citizenship and the confiscation of property (С̆TK, Feb. 17 1995, 40).

In this context, the Czech communists started to push strongly for the expulsion of the Sudeten Germans. From their point of view such a stance could only be of benefit to their party and its popularity as an antithesis of Nazism and right-wing politics. Subsequent programs of nationalisation were a direct result of the desire to move as far away as possible from the extreme right-wing politics and policies of the war years, and the fact that these programs also resulted in Germans losing their property was regarded popularly as an added bonus. Also, aside from the Sudeten Germans, there was a population of

\footnotetext{
2 Beneš was warned by Anthony Eden about the potential dangers of apply the principle of guilt to the expulsion of the Sudeten Germans, as a restrictive mechanism in relation to the number of transferees (Zeman 1991, 209). Also see Doc. 148, 23 November 1944, 'Memorandum of the Czechoslovak government on the transfer of Germans from Czechoslovakia' (Vondrová 1994, 303-8).
} 
Reichsdeutsche in the Czechoslovak Republic that numbered approximately 100,000 people. All people of German nationality found themselves in a reverse situation to that had applied at the time of the Protectorate. Now the Germans were given less rations than the Czechs and were forced to wear armbands bearing the letter ' $N$ ' for Němec (German) 3 . The months immediately after the war were particularly strained as small areas of Nazi resistance remained in the region. Added to this, some of the Czechs who had returned from German concentration camps were appointed to positions of authority from which they were able to vent their feelings of hatred against the Sudeten Germans and succeeded in fuelling Czech nationalism. Czechs who had been expelled from their homes in the Sudeten regions after the Munich agreement started to return to the region, along with looters and other revenge seekers. This brought about a situation of frontier justice; many loyal Sudeten Germans found themselves at the mercy of a mob sanctioned by the Interior Ministry under the control of the communists. Some moderate members of the Beneš government attempted to avert the impending disaster, but with no success. The Czechs remained convinced that the Sudeten Germans still had, and were pursuing, their agenda of undermining the state.

\section{Wild expulsions and organised transfers}

The Potsdam Peace Conference did not initiate the idea of transferring or expelling the German population from the countries of Eastern Europe. Rather, it merely gave Allied approval to a measure that was already taking place. When Beneš returned to Prague in May 1945, he publicly announced his program for the expulsion of the Sudeten Germans. In many ways, this announcement sanctioned the start of the period that was known as the 'wild expulsions,' which lasted until the autumn of 1945. The number of Sudeten Germans expelled from the Czechoslovak Republic came to about three million. The exact figures for the numbers vary according to the different studies undertaken on the Czech and Sudeten German sides. However, there is consensus that prior to the Potsdam Conference a significant portion of Sudeten Germans were either expelled as a result of the 'wild expulsions,' or fled the country ahead of the liberating armies. When the Potsdam

\footnotetext{
3 As a result of the introduction of the Beneš Decrees many of the rights and freedoms previously experienced by Sudeten Germans as citizens were removed (Die Sudetendeutschen 1995, 152).
} 
Conference put an end to the 'wild expulsions' there were some 800,000 fewer Sudeten Germans in the Czechoslovak Republic than at the time of the Munich Agreement. ${ }^{4}$

At the Potsdam conference it was agreed that the borders of Germany would revert to 1937 boundaries, and that the Sudeten regions claimed by Germany at Munich would revert to the Czechoslovak state. The conference also outlined a policy for the settlement of German refugees, and accepted the transfer of the German minorities from the Czechoslovak Republic, Poland and Hungary (Grenville 1987, 224). In ending the 'wild expulsions' the Potsdam Conference thus sanctioned a more orderly transfer of the Sudeten German population. The allocation of these expellees was divided up in the following way: Soviet zone: 750,000 from Czechoslovakia and 2,000,000 from Poland, British zone: 1,500,000 from Poland, American zone: 1,750,000 from Czechoslovakia and 500,000 from Hungary, and French zone: 150,000 from Austria (Bauer 1995, 89). As far as the Czechs were concerned the most important decision was Allied recognition for the expulsion of the Sudeten Germans. However, the Conference also deemed that the expulsions should be stopped until the required infrastructure could be established in the occupied zones in Germany (Wiskemann 1956, 110). The end of the forced expulsions thus brought to an end a particularly turbulent phase in the relationship between the Sudeten Germans and the Czechs.

\section{A lasting solution to the minorities problem - the initial post-war years}

The situation in the Czechoslovak Republic after the war was a difficult one. When the transfers of the Sudeten Germans were postponed, the Czechs took action to try and minimise the reaction of the Czech population. Several schemes were initiated, including a compulsory work scheme that was introduced in part to ensure that the economic situation was improved after years of German/Nazi usurpation. The Sudeten Germans who remained in the country were faced with three choices: to clear their names of any Nazi related activities; to contribute their specialised work skills to the Czech economy; or, for those who did not satisfy the first two options, internship in camps. The aim of the camps was to diffuse some of the tension in the community by removing the Sudeten Germans,

\footnotetext{
${ }^{4}$ In this first wave of expulsions between 700000 and 800000 Sudeten Germans were removed from Czechoslovakia, of these 150000 were sent to Austria and the others to Germany (Bundesministerium fur Vertriebene 1994, 112).
} 
and to serve as collection centres for those who were to be expelled (Zeman 1991, 122; Schmidt-Hartmann, 1996).

The integration of the German refugees and expellees into Germany took place over a four-year period after the war, from 1945 to 1949. The experiences and integration processes of these people varied according to where they came from and where in Germany they ended up. The fate of the expellees who ended up in the Soviet occupied zone of Germany differed from those in the Western occupied zones. Some 1.75 million Sudeten Germans, the largest group, ended up in the American zone, while approximately 750,000 had originally been sent to the Soviet zone a number of these people later fled to West Germany (De Zayas 1988, 101).

The largest number of Sudeten Germans found themselves in Bavaria (Bauer 1995, 199215), part of the American zone. At first they received a cool reception as many Germans felt that they had helped to bring about the war in Europe. Also, the arrival of so many ethnic Germans became a highly visible reminder of having lost the war (Kuhn 1989, 177). This perception was not improved by the Sudeten Germans' cultural traditions, which were seen to be fundamentally different to those of the existing German population. Many Sudeten Germans found themselves having to adapt to a reformulated identity, one that would provide them with a semblance of belonging. Others were extremely resentful of the loss of cultural characteristics that for them were representative of their identity, for example their dialect. This view was taken to great lengths by some of the Sudeten Germans who were opposed to mixed marriages, seeing themselves as ethnically distinct from the Germans of their host society (Larres et al. 1996, 40-41). Although ethnically German, these Sudeten Germans had evolved as part of Austria, in a different national environment, and regarded themselves as members of a group with a distinct history and culture, and a distinct nationality. Some Sudeten Germans felt that it was their patriotic duty to resist any attempts at integration, as this might be interpreted as giving up on claims to their right to self-determination.

It was not until 1947 that the first expellee policy in the occupied zones was adopted, which allowed for 'uniform integration and implementation procedures on a zonal rather than a state or local basis' (Schoenberg 1970, 45). Following this the American authorities established special advisory boards at all legislative and administrative levels to oversee 
refugee and expellee affairs. The membership of these boards consisted of equal numbers of West Germans and expellees. The developments in this area took place over a number of years. The Marshall Plan was to play a useful role in 1948 in these developments, given that 'the authorities of the Plan made nearly sixty million dollars available exclusively for the needs of German expellees and refugees' (Paikert 1962, 24).

Grosser raises the point with regard to the integration of the expellees that in the case of Germany, the term integration was not synonymous with assimilation. The reason for this was that if the government were to try and assimilate the expellees it might be seen to be admitting or recognising the Oder Neisse border, thus effectively putting an end to calls for the return of the homelands of the expellees. This terminological distinction was also supported by the Landsmannschaften, associations of ethnic Germans from Central and Eastern Europe, who saw that it was to their own political advantage if the government pursued this line of reasoning (Grosser 1978, 274). Again, these positions iterate how each of these expellee groups perceived that they had their own distinct national identity. They felt that assimilation would negate this sense of national belonging and would result in their inability to make future claims for self-determination on the grounds of being distinct nations.

\section{The path to normalisation of relations between Czechs and Sudeten Germans}

From a Czech point of view, even prior to the communist coup of 1948, concerns were being raised in the government about the potentially divisive nature of the Sudeten Germans abroad, thereby making the process of normalisation of relations a difficult one. Toward the end of the 1960s, at the time when West Germany was seeking to re-establish relations with Czechoslovakia, and with the signing of the Prague Treaty (1973), the Sudeten Germans commenced a vigorous program of lobbying for their perceived rights and for recognition and upholding of the rights of ethnic Germans remaining in Czechoslovakia.

The situation in West German politics in normalising relations with the countries of Eastern Europe, and in particular Czechoslovakia, followed a different path to that taken in relation to East Germany. The main reason for this was the influence of the expellees and refugees who had been able to gain a political voice. Specifically, the Sudeten German 
problem for West Germany was the fact that they had inherited the border problems as a legacy of Hitler's Germany and of the Munich Agreement. Therefore, on behalf of the expellees, including the Sudeten Germans, West Germany demanded their right to a homeland. These demands led other countries, both from the west and east, to interpret these calls as a means for Germans to return to the territories from which they had been expelled. Following from this, fears were raised that once such populations had re-instated themselves by way of self determination, they would be able to re-include themselves into the territory of Germany. Thus, the development of West Germany's Ostpolitik was hampered not only by internal party politics disputes but also by external perceptions. Thus, the main source of contention between the Czechs and the Germans, including the Sudeten Germans, were the legacies of Munich. West Germany was still the only state not to recognise the Munich Agreement as invalid, and the Sudeten Germans in Germany were determined not to allow the German government to recognise its invalidity.

From the point of view of the Sudeten Germans the Prague Treaty left unresolved the issue of their right to their homeland and to self-determination, two inalienable human rights that could not be relinquished. The Sudeten German Landsmannschaft in Bavaria continued to maintain that the treaty would ultimately fail, as it had not been concluded with their direct participation. The Landsmannschaft proceeded to use this argument to reassert their influence when post-1989 negotiations started between Germany and Czechoslovakia for a new treaty of friendship and good neighbourliness. The old issues that were debated during the negotiations surrounding the Prague Treaty resurfaced once again. This time, however, they were further complicated by the Czechoslovak restitution laws that were introduced with a cut-off date of 1948. Change in the political sphere ushered in the potential for renewed attempts at reconciliation; however the process of achieving this goal was not to be a simple one, and had an impact on the exile experiences of many people.

\section{Czechs after 1989 and restitution}

For the Sudeten Germans, the changes underway in Czechoslovakia after 1989, in an atmosphere of democracy, signalled a potential opportunity for a redress of their grievances and potential reconciliation, especially given that so many changes and new legislation were being introduced. This period brought to a forefront in a Czech forum the 
many issues that the Sudeten Germans had been discussing in Germany in the post-war years and were now able to discuss openly in their former homeland. However, the fundamental elements of the Sudeten question remained unresolved during this period despite continued negotiations and the signing of a new treaty of friendship between the two states in 1992. The new era of reconciliation was to leave many Sudeten Germans disappointed as it focussed on the future with nothing more than a verbal acknowledgment of past injustices. The situation after the Velvet Revolution, and the fact that Czechoslovakia, and later the Czech Republic, modelled themselves closely on the First Republic, rekindled old fears and grievances on both the Czech and German side in relation to the Sudeten Germans. These fears were on several occasions exacerbated by Sudeten German associations based in Germany. Whilst the Munich Agreement was nullified, issues concerning the Beneš decrees and their possible negation, and questions regarding restitution were very much alive.

In Germany, the Sudeten community was still adhering to its long established policies on reconciliation and restitution, in place since the post-war expulsions. From the Sudeten point of view, the signing of a new friendship treaty between the Czechs and Germans presented an opportunity for their grievances to be redressed. This feeling was encouraged by developments in Czech politics in the area of coming to terms with the past, with the new government attempting to right the wrongs of the previous regime. The principles put forward by the Sudeten Landsmannschaft were comprised of the following: a renunciation of retribution and revenge for the events surrounding the expulsions: a claim for restitution of all losses that had resulted from the expulsions; a claim that their homeland be returned to them; and a claim that they had a legitimate right to pursue self determination (Blumenwitz 1985, 117-18). The last two claims had existed since the establishment of the first Czechoslovak republic. The process by which the Czechs tried to deal with these unresolved questions from the past is central to the reconciliation debate. That debate has been marked by the development of a new political relationship between the Germans and the Czechs on a state level, and by the discussions of the moral dimensions of the Sudeten case at a Presidential and intellectual level. The reconciliation process remained divided between the intellectual push towards a dialogue and the populist approach to the problem. However, there would seem to a common viewpoint on the Czech side that the Sudeten Germans were victims of their own actions and therefore not entitled to participate in the 
restitution process. The isolation of the Sudeten Germans in the form of a lack of external support delegitimised their claims (Barkan 2000, 140-41).

In January 1991, the German government decided to avoid any questions relating to compensation or ownership in the treaties to be concluded with Poland and Czechoslovakia. Negotiations for the treaty with Czechoslovakia commenced in March. This was followed by a statement by Czech Premier Petr Pithart to parliament that property confiscated prior to 25 February 1948 would not be returned, in accordance with the Czechoslovak restitution law. At the same time, it was announced that there would be no rescinding of the Beneš decrees by any Czechoslovak government. Both policies came under question by the Czech media and politicians, and inspired strong lobbying by various Sudeten German organisations. However, the Czech government has stood firm on both policies. Despite occasionally giving out contradictory statements and fighting a case in the Constitutional Court against the Beneš decrees, no changes in policy have been made. In treaty negotiations the Czechoslovak foreign ministry conceded that it would accept a zero option where no property claims would be made by either side; however it insisted that this would in no way affect Czechoslovak claims for compensation by victims of Nazism. By September 1991, when a draft of the treaty had been prepared, the Sudeten German Landsmannschaft (through its spokesperson Franz Neubauer) spoke out strongly against this document, stating that Sudeten Germans grievances were not addressed, namely restitution of property and right to homeland, and again calling for direct talks between the Sudeten Germans and the Czechoslovak government. Despite this dispute, finally in February 1992 the Czechoslovak-German treaty on 'Good Neighbourly Relations and Friendly Cooperation' was signed in Prague. The treaty was ratified by the Czechoslovak Federal Assembly on April 22, and by the Bundestag on May 20 and the Bundesrat on June 26, 1992.

\section{Restitution and return}

Following the collapse of communism in Eastern Europe there was widespread feeling that the wrongs committed by the previous regime needed to be corrected as a means of dealing with the past. Many countries, Czechoslovakia included, chose to adopt various forms of restitution legislation as a means of redressing grievances against the old regime. Restitution became a political mechanism for ensuring some form of negotiated justice. In 
the countries in transition during the 1990s, the restitution process promised a fast route to capitalism and privatisation, with the benefit of establishing economic viability and a stable state (Barkan 2000, xxxiv, 112). Restitution has been defined in the following way: 'one way among others to transfer state-owned assets to private holders of property titles on the basis of rights' (Offe et al. 1993 30). On one level states saw restitution as a means to simply return property to private ownership, a way of reversing one of the pillars of communist ideology. However, restitution also raised questions about whether such a practice was in itself not creating further moral wrongs: 'any attempt to compensate for known wrongs will only move us from one morally objectionable situation to another' (Sher 1993, 38). Wrongs were defined as actions that resulted in the removal of fundamental rights, liberties and freedoms from citizens.

Political theorists also turned their discussion to the fact that by correcting the moral wrongs of the past, restitution laws were also simultaneously shaping the national identities of the new states in the early post-communist period. For Avineri, the restoration of rights occurred only in a specific historical context that, in turn, circumscribed the conditions of restitution and reparations. Not only was restitution law a victory of norms of private property over communist ideology and practice, it was also a means of constructing a post-communist national identity (Avineri 1993, 35). Holmes has raised the question that if together economic and moral arguments against restitution seem unbearable, why is the process continuing? Approaching the debate from the standpoint that the concept of restitution is morally unjust, he concludes that it is good policy if such a cleansing process will assist in the establishment of a new democratic system (Holmes 1993, 33).

In the case of the Sudeten Germans, however, the problem was not a matter of simply identifying the victims. In a collective sense this was easily recognised, but on an individual level it was slightly more difficult, as it required distinguishing between distinct levels of guilt (or innocence). This posed a dilemma in much the same way as that faced by Czechs in relation to dealing with communist collaborators and the choices presented in the lustration law. There were also the additional questions of to what extent should property be restituted and where should the cut off point be. Although 'Compensation for losses presupposes proof of loss' (Offe et al. 1993, 25), it is obviously easier to provide proof in some cases like confiscation or imprisonment than in cases like ill-health or loss 
of opportunity stemming from displacement; a situation exacerbated because documentation required for proof can be difficult to obtain. Many questions must be tackled and resolved if any form of reconciliation process is to be achieved between those who are perceived to have done wrong and those who have been wronged, as can be summed up by the following statement: 'the discourse of restitution aims at the morally possible, not at the politically utopian' (Barkan 2000, 349).

The process of correcting past wrongs generated great debate and deliberation in Czechoslovakia after the Velvet Revolution. The resulting series of rehabilitation and restitution laws sought to provide some recompense for injustices committed by the communist regime. From a Czech government perspective the main rationale for adopting any form of restitution legislation was simply to put into place a mechanism for returning property into private ownership. On the one hand, this would reverse the program of nationalisation that had been implemented by the previous regime. On the other hand, restitution was also seen as being the fastest, and most direct, way of re-establishing private ownership (Jezek 1997, 482). A concern on the part of several politicians was that returning property to its original owners might slow the privatisation process down, due to potential legal controversies resulting from questions of ownership or inheritance rights. However Havel, as president, was consistently a strong supporter of the restitution legislation and its aims to achieve 'historical justice' while 'not slow[ing] down or hinder[ing] the country's radical economic reforms' (Bren 1994, 18).

The process of legislating for the return of property to private ownership, and the system of restitution did not occur in one simple step. In fact a number of laws passed in 1990 and 1991 related to the issue of restitution, and several laws concerned with the privatisation of industry by the voucher method were also introduced. After the division of Czechoslovakia, both the Czech Republic and Slovakia inherited the restitution laws and the legal framework that had been previously established. In the Czech Republic, the focus of the restitution debate soon turned to the Sudeten Germans, as well as to the restitution of Jewish property and that of the former nobility.

Yet, while the large restitution law did ensure that many people received compensation, it did not include those who had had their property confiscated prior to February 1948. The cut-off date in an otherwise generous restitution law was chosen to preclude the Sudeten 
Germans from claiming back their property, as did the new citizenship and residency requirements enshrined in the legislation, which made the process difficult for emigrants. It should be pointed out that all political parties were in agreement over this legislation, with some even wanting to prevent the Sudeten Germans from returning to the country. In relation to émigrés and the restrictions placed on them by the restitution laws, changes to the act came after a long drawn out process of lobbying. Amendments made to this large restitution law in subsequent years included the restitution of property confiscated prior to 1948 to those Germans who had remained in Czechoslovakia, for example spouses of Czech citizens, and those who had been affected by the confiscations. After 1948 these people had Czech citizenship, but not their property, returned to them (Bren 1994, 20).

By May 1994 there was renewed pressure on the Czech government to start a dialogue with the Sudeten Germans. This coincided with discussion of rescinding the Beneš decrees (Kohler 1995, 6), which was initiated by a Czech of German origin, Rudolf Dreithaler, who lodged a petition in the Czech Constitutional Court. His petition sought principally a re-examination of the constitutionality of Beneš decree no. 108, concerned with the confiscation of property from disloyal minorities (Pehe 1994, 12). The reconciliation process between the Sudeten Germans and the Czechs during the genesis period, and attempts at dealing with the different exile experiences, thus seemed to become focused on one issue, the debate over restitution versus compensation (Kubes 1995, 3). The debate again confirmed that despite the post-World War Two Czech Government's attempt to secure a lasting solution to the 'disloyal' minority of the Sudeten Germans in the form of their expulsion, the result would be a long-lasting stalemate between calls for restitution on the Sudeten side, and calls for compensation on the Czech side.

\section{The return of the old ghosts of exile experience}

In March 1995, the Czech Constitutional Court made a significant decision in relation to the Sudeten question by rejecting the abolition of Beneš Decree 108 (confiscation of the enemy's property and on nation restoration funds). Also, German opposition parties started to urge the Bundestag to take decisive action on the matter of compensation for Czech victims of Nazism, and to make a government statement on bilateral relations.

Reconciliation between the Czechs and Sudeten Germans seemed to reach a tense standoff when discussions became focussed on righting past wrongs, namely providing 
compensation for damages sustained by individuals both during and after the war. One of the central truths of the debate appeared to be that remedies sought to rectify injustices of the past inevitably lead to emotional debates and cries of further injustices. The euphoria of 1989 and the subsequent transition to a free market resulted in the adoption of many new laws attempting to change or redress the so-called wrongs of the previous communist regime. The split of Czechoslovakia in 1993 was in itself a peaceful one; however in relation to the Sudeten German question a new storm started to brew; namely, the issue of restitution of property confiscated after the war, and the right to return. The question of restitution was in itself a controversial one, given the implications it held for acknowledgement of Sudeten German grievances. At the centre of the controversy was the fact that, since 1989, the Czech government had consistently expressed the view that the return of property to the former Sudeten German minority was out of the question.

The year 1995 was to mark a turning point in the road towards reconciliation and dialogue between the Czech Republic and Germany over the Sudeten question, although still not directly with the Sudeten Germans. In a speech in May that year, Premier Klaus expressed his regret at the injustices suffered by the Sudeten Germans after World War II. He called for a rapprochement between the Sudeten Germans and the Czechs, but also made the point that success would rest very much on the attitude of Czech politicians (ČTK Press Reports, 1995). At that point in time both governments had reached consensus on one fact, namely that they would not allow nationalist sentiments to hamper developments in Czech-German relations. This was again a significant step forward, and to all intents and purposes marked the end of this phase of the cycle of guilt and freedom in relation to the varied experiences of exile in the Czech lands.

\section{Reference List}

Avineri, S A. 1993, Forum on Restitution, East European Constitutional Review, vol.2, no.3, Summer.

Barkan, E. 2000, The Guilt of Nations. Restitution and Negotiating Historical Injustices, W.W. Norton, New York.

Bauer, F J. 1995, Aufnahme und Eingliederung der Flüchtlinge und Vertriebenen. Das Beispiel Bayern 1945 - 1950, in Benz, W (ed.), Die Vertreibung der Deutschen aus dem Osten, Fischer Taschenbuch Verlag, Frankfurt am Main.

Blumenwitz, D. 1985, Der Prager Vertrag, Kulturstiftung der deutschen Vertriebenen, München.

Bren, P. 1994, Czech restitution laws rekindle Sudeten Germans' grievances, $R F E / R L$ Research Report, vol. 3, no. 2, 14 January. 
Campbell, G F. 1975, Confromtation in Central Europe. Weimar Germany and Czechoslovakia, University of Chicago Press, Chicago.

Cornwall, M. 1992, Dr Eduard Beneš and Czechoslovakia's German minority, in Morison, $\mathrm{J}$ (ed.), The Czech and Slovak Experience, St Martins Press, New York.

Crane, J O. Crane, S. 1991, Czechoslovakia: Anvil of the Cold War, Praeger, New York.

ČTK Daily News (Czech Press Agency), Prague, Czech Republic.

De Condole, J. 1993, Czechoslovakia: The End of an Illusion, Institute for European Defence and Strategic Studies, Prague.

De Zayas, A. 1988, Nemesis at Potsdam: The Expulsion of the Germans from the East, $3^{\text {rd }}$ ed., University of Nebraska Press, Lincoln.

Die Sudetendeutschen - Eine Volksgruppe im Herzen Europas 1848 - 1988 von der Frankfurter Paulskirche zur Bundesrepublik Deutschland,, 1995, Sudetendeutscher Rat, München.

Bundesministerium fur Vertriebene, Fluchtlinge und Kriegsgeschadigte, 1994, Die Vertreibung der deutschen Bevölkerung aus der Tschechoslowakei - Eine Dokumentation, vol. 1, Herausgegeben vom ehemaligen Bundesministerium fur Vertriebene, Fluchtlinge und Kriegsgeschadigte, Weltbild Verlag, Augsburg.

Grenville, JAS. 1987, The Major International Treaties 1914-1945, Methuen, London. Grosser, A. 1978, Geschichte Deutschlands seit 1945, 6th ed, dtv, München.

Habermas, J. 1998, The Inclusion of the Other. Studies in Political Theory, ed. by C. Cronin, P de Greiff, Polity Press, Cambridge.

Havel, V. 1994, Toward a Civil Society, Nákladatelstvi Lidové Noviny, Prague.

Holmes, S. 1993, A Forum on Restitution, East European Constitutional Review, vol.2, no.3, Summer.

Jaspers, K. 1967, Philosophy is for Everyman: a short course in philosophical thinking, transl. Hull, R F. Wells, G. Harcourt Brace and World, New York.

Jezek, T. 1997, The Czechoslovak Experience with Privatization, Journal of International Affairs, vol. 50, no. 2, Winter.

Kohler, B. 1995, Schutzwall für die Beneš-Dekrete: Die tschechischen Reihen sind geschlossen, Frankfurter Allgemeine Zeitung, March 10.

Kral, V. 1964, Die Deutschen in der Tschechoslowakei 1933 - 1947.

Dokumentensammlung., Nakladatelství, Československé Akademie Věd, Prague.

Kubes, M. 1995, Positive Stimmen in der tschechischen Presse: 'Die Vertreibung war Unrecht - machen wir es wieder gut!', Sudetendeutsche Zeitung, 11 August 1995, München.

Kuhn, E. 1989, Nicht Rache, nicht Vergeltung, Ullstein, Frankfurt am Main.

Larres, K. Panayi, P. 1996, The Federal Republic of Germany since 1949, Longman, London.

Macartney, C A. 1996, National States and National Minorities, in Woolf, S. (ed.) Nationalism in Europe 1815 to the Present. A Reader. Routledge, London.

Offe, C. Bönker, F. 1993, A Forum on Restitution, East European Constitutional Review, vol.2, no.3, Summer.

Paikert, G C. 1962, The German Exodus. A Selective study on the post-World War II Expulsion of German Populations and its Effects, Martinus Nijhoff, The Hague.

Paneth, P. 1943, Eduard Beneš A Leader of Democracy, Alliance Press Limited, London.

Pehe, J. 1994, The Czech Republic: A Successful Transition, RFE/RL Research Report, Vol. 3, No. 1, January.

Prinz, F. 1995, 'Odsun Němců', die Vertreibung der Sudetendeutschen 1945: Ein kritischer Rückblick, in Odsun. Die Vertreibung der Sudetendeutschen. Beglietband zur Ausstellung, Sudetendeutsches Archiv, München. 
Roucek, J S. 1948, Central Eastern Europe. Crucible of World Wars, Prentice Hall, New York.

Schmidt-Hartmann, E. 1996, Tschechoslowakei, in Benz, W, Dimension des Völkermords. Die Zahl der judischen Opfer des Nationalsozialismus, dtv Wissenschaft, München.

Schoenberg, H W. 1970, Germans from the East, A Study of their Migration, Resettlement, and Subsequent Group History Since 1945, Martinus Nijhoff, The Hague.

Sher, G. 1993, A Forum on Restitution, East European Constitutional Review, vol.2, no.3, Summer.

Taborsky, E. 1945, Czechoslovak Democracy at Work, Allen \& Unwin, London.

Vondrová, J. (ed.), 1994, Češi a sudetoněmecká otazká 1939 - 1945, Dokumenty, Ústav mezinárodních vztahů, Praha.

Wiskemann, E. 1956, Germany's Eastern Neighbours. Problems Relating to the OderNeisse line and the Czech Frontier Regions, Oxford University Press, London.

Zeman, Z. 1991, The Making and Breaking of Communist Europe, Basil Blackwell, Oxford. 